\title{
SISWA DALAM MENYELESAIKAN SOAL OPERASI PENJUMLAHAN PADA BILANGAN PECAHAN DAN REVERSIBILITAS
}

\author{
Lalu Saparwadi $^{1}$, Baiq Purnawati ${ }^{2}$, Baiq Puspa Erlian ${ }^{3}$ \\ ${ }^{1}$ Universitas Hamzanwadi, ${ }^{2}$ SMPN 2 Sukamulia, ${ }^{3}$ SMK Mapar Selong \\ Email: lalusaparwadi@gmail.com
}

\begin{abstract}
Abstrak
Tujuan penelitian ini adalah mengetahui jenis-jenis kesalahan siswa dalam menyelesaikan soal operasi penjumlahan bilangan pecahan dan operasi bilangan pecahan terkait reversibilitas. Metode yang digunakan dalam penelitian ini adalah penelitian deskriptif. Hasil penelitian menemukan bahwa kesalahan yang ditemukan dari hasil kerja siswa dalam menyelesaikan soal operasi penjumlahan bilangan pecahan dan operasi bilangan pecahan terkait reversibilitas, yaitu antara lain: (1) Siswa masih memendang bahwa penjumlahan pecahan sama seperti aturan dalam penjumlahan bilangan bulat; (2) Lemahnya kemampuan siswa dalam membalikan pemikiran mereka dalam menggambarkan kondisi awal penjumlahan berdasarkan hasil yang diketahui dari penjumlahan tersebut; (3) Lemahnya kemampuan siswa dalam menggambarkan penjumlahan dua pecahan yang melibatkan bilangan negative berdasarkan hasil penjumlahan yang telah diketahui; (4) Lemahnya kemampuan siswa dalam membangun hubungan yang reversibel.
\end{abstract}

Kata Kunci : kesalahan, bilangan pecahan, reversibilitas

\section{PENDAHULUAN}

Operasi bilangan pecahan merupakan salah satu materi matematika di tingkat SMP/MTs kelas VII berdasarkan kurikulum yang digunakan di Indonesia tahun pelajaran 2017/2018. Salah satu tujuan pembelajaran pada pokok bahasan bilangan pecahan adalah siswa dapat menyelesaikan soal yang berkaitan dengan operasi hitung pecahan serta menggunakannya dalam pemecahan masalah (Mustikasari, dkk, 2014). Untuk mencapai tujuan pembelajaran tersebut secara maksimal, tidak cukup hanya memberikan soal operasi secara langsung dalam satu arah seperti yang terdapat pada sebagian besar buku. Tetapi diperlukan model soal yang dapat membawa siswa untuk membalikan pemikirannya dalam proses pemecahan. Salah satu bentuk soal yang dapat membalikan pemikiran siswa yaitu soal yang terkait dengan reversibilitas. Membalikan pemikiran dalam menyelesaikan soal juga merupakan bukan sesuatu yang mudah. Tetapi dibutuhkan pemangilan beberapa informasiimformasi pengetahuan yang dimiliki sebelumnya sebagai dasar untuk melakukan proses pembalikan pemikiran. 
Kemampuan seseorang mengembalikan arah pemeikirannya kembali ketitik awal setelah melakukan operasi mental disebut reversibilitas (Kang dan Lee, 1999). Operasi mental merupakan aktivitas mental yang dilakukan seseorang ketika menggunakan operasi hitung (Maf'ulah, 2016: 29). Membangun hubungan dua arah merupakan suatu tindakan yang digunakan untuk membentuk keadaan awal dari hasil yang diperoleh berdasarkan proses sebelumnya. Menurut Piaget (1970) tindakan reversibel dapat terjadi dalam satu arah atau sebaliknya, dan ini tidak berlaku untuk semua tindakan. Sebagai contoh, menjumlahkan dua bilangan sehingga diperoleh hasil, dan hasil penjumlahan tersebut dapat digunakan untuk memperoleh salah satu dari bilangan melalui pengurangan dari hasil penjumlahan sebelumnya dengan salah satu bilangan yang ada untuk memperoleh bilangan yang lainnya. Menurut Ramful (2015) masalah-masalah yang terkait dengan reversibilitas dalam belajar matematika, antara lain: pecahan, persentase, aljabar, dan data. Materi opersi pecahan yang terdiri dari penjumlahan, pengurangan, perkalian dan pembagian harus benar-benar dipahami dari segi konsep, prosedur, serta keterampilan dalam berhitung guna menghindari adanya kesalahan-kesalahan yang dialami siswa ketika menyelesaikan masalah terkait dengan pecahan.

Beberapa peneliti telah melakukan penelitian yang terkait dengan operasi bilangan pecahan. Widiyanti, dkk (2014) melakukan penelitian untuk mengetahui jenis kesalahan dan faktor yang menyebabkan siswa melakukan kesalahan dalam menyelesaikan soal pecahan bentuk aljabar. Berdasarkan hasil penelitian yang dilakukan bahwa siswa yang melakukan kesalahan yang paling banyak adalah pada sub materi menyederhanakan bentuk pecahan. Salleh, dkk (2013) mengkaji jenis kesalahan dan pola kesalahan sistematis yang sering dilakukan oleh siswa dalam operasi penjumlahan dan pengurangan pecahan. Untari (2014) mengkaji penyebab kesulitan belajar siswa dalam menyelesaikan soal pecahan dalam berbagai macam operasi hitung. Halimah, dkk (2013) mengungkapkan bahwa siswa merasa kesulitan setiap kali menemukan materi pecahan. Apriyanto (2012) mengkaji tipe-tipe kesalahan yang dilakukan siswa dalam menyelesaikan soal operasi bilangan pecahan.

Berdasarkan hasil dari beberapa penelitian yang pernah dilakukan, pecahan merupakan materi yang kompleks dan sulit untuk dipahami anak-anak (Niekrek, et al, 1999). Makna pecahan yang cukup bervariasi merupakan salah satu juga sebagai penyebab kesulitan siswa dalam pembelajaran pecahan (Sari, dkk, 2014). Sementara di sisi yang berbeda, pecahan juga sangat berguna bagi siswa karena melalui konsep pecahan akan memebantu mereka untuk mempelajari matematika yang lain dijenjang berikutnya, seperti pecahan dalam bentuk aljabar, perbandingan dalam geometri, dan materi matematika yang lainnya. Kurangnya pemahaman siswa tentang pecahan merupakan faktor yang berkuntibusi pada lemahnya penguasaan materi matematika siswa (Mullis, et al, 1997). Oleh karena itu, kesalahan siswa dalam menyelesaikan soal-soal pecahan perlu digali secara mendalam untuk memperoleh informasi terkait dengan faktor yang menyebabkan kesalahan.

Untuk mengetahui kejelasan informasi yang menyebabkan siswa melakukan kesalahan dalam menyelesaikan soal-soal pecahan, terutama terkait dengan operasi hitung 
dan reversibilitas siswa. Oleh karena itu, penelitian ini akan memfokuskan pada identifikasi kesalahan yang dilakukan siswa dalam menyelesaikan soal operasi penjumlahan bilangan pecahan dan operasi bilangan pecahan terkait reversibilitas pada siswa tingkat SMP kelas VII semester 1 .

\section{METODE}

Penelitian ini dilakukan untuk mengetahu jenis-jenis kesalahan siswa dalam menyelesaikan soal operasi penjumlahan bilangan pecahan dan mengetahui pemikiran sebaliknya terkait reversibilitas siswa dalam menyelesaikan soal pecahan. Metode yang digunakan dalam penelitian ini adalah penelitian deskriptif. Menurut Nawawi dan Martini (1992: 23) metode deskriptif merupakan prosedur atau cara memecahkan masalah dengan memaparkan keadaan objek yang diselidiki (seseorang, lembaga, masyarakat, dan lain-lain) sebagaimana adanya berdasarkan fakta-fakta yang aktual pada saat sekarang.

Penelitian ini dilaksanakan di SMP Negeri 2 Sukamulia Kabupaten Lombok Timur Provinsi Nusa Tenggara Barat. Penelitian ini didasarkan hasil wawancara dari salah satu guru mata pelajaran matematika kelas VII yang menyatakan kemampuan siswa dalam menyelesaikan soal penjumlahan pecahan cukup bervariasi untuk materi pecahan. Soal operasi penjumlahan pecahan terkait dengan reversibilitas siswa dalam menemukan nilai yang hilang pada penjumlahan dua bilangan pecahan ketika hasil dari penjumlahannya sudah diketahui, belum pernah diberikan. Oleh karena itu, subjek penelitian ini difokuskan pada siswa kelas VII SMPN 2 Sukamulia semester 1 yang telah selesai memperoleh materi operasi bilangan pecahan.

Teknik pengumpulan data yang digunakan dalam penelitian ini adalah tes. Tes digunakan untuk mendapatkan data tentang gambaran kemampuan subjek dalam menyelesaikan soal operasi penjumlahan pecahan dan operasi bilangan pecahan terkait reversibilitas.

\section{HASIL DAN PEMBAHASAN}

Tujuan penelitian ini adalah mengetahui jenis-jenis kesalahan siswa dalam menyelesaikan soal operasi penjumlahan bilangan pecahan dan operasi bilangan pecahan terkait reversibilitas. Hasil penelitian ini diawali dengan menghitung jumlah siswa yang menjawab dengan benar dan jumlah siswa yang menjawab dengan tidak benar. Selanjutnya medeskripsikan kesalahan yang dilakukan berdasarkan hasil kerja siswa.

Berikut adalah tabel hasil pekerjaan siswa dalam menyelesaikan soal penjumlahan pecahan dan operasi bilangan pecahan terkait reversibilitas siswa.

Tabel 1. Hasil tes kemampuan siswa dalam menyelesaikan soal penjumlahan pecahan.

No Soal Hasil kerja siswa




\begin{tabular}{cccccc} 
& & \multicolumn{2}{c}{ Benar } & \multicolumn{2}{c}{ Salah } \\
\cline { 3 - 6 } & & Jumlah & $\begin{array}{c}\text { Persentase } \\
(\%)\end{array}$ & Jumlah & $\begin{array}{c}\text { Persentase } \\
(\%)\end{array}$ \\
\hline 1. & $\frac{3}{4}+\frac{3}{2}=\ldots$ & 15 & 34,9 & 28 & 65,1 \\
2. & $\ldots+\frac{3}{5}=1$ & 5 & 11,6 & 38 & 88,4 \\
3. & $\frac{3}{2}+\ldots=1$ & 0 & 0 & 43 & 100 \\
\hline
\end{tabular}

Hasil tes yang disajikan pada tabel 1 menunjukkan bahwa siswa yang menjawab benar pada soal nomor 1 sebanyak 15 orang atau sebesar 34,9\% dari keseluruhan jumlah siswa yang mengikuti tes yaitu sebanya 43 siswa, dan jumlah siswa yang menjawab salah sebanyak 28 siswa atau sebesar $65,1 \%$ dari keseluruhan siswa yang mengikuti tes. Untuk soal nomor 2, jumlah siswa yang menjawab dengan benar sebanyak 5 orang atau sebesar 11,6\% dari keseluruhan siswa yang mengikuti tes, dan jumlah siswa yang melakukan kesalahan dalam menyelesaikan soal nomor 2 sebanyak 38 orang atau sebesar $88,4 \%$ dari keseluruhan siswa yang mengikuti tes. Untuk soal nomor 3, tidak ada siswa yang menjawab dengan benar, artinya semua siswa yang mengikuti tes tidak ada yang berhasil dalam menyelesaikan soal pada nomor 3. Ketidakberhasilan tersebut sangat terkait dengan model soal untuk nomor 3 merupakan baru bagi siswa, meskipun jenis materi dalam soal tersebut mereka telah pelajari sebelumnya. Ini juga didukung berdasarkan hasil wawancara guru mata pelajaran matematika sebelum memberikan soal penjumlahan pecahan terkait dengan reversibilitas.

Letak kesalahan yang dilakukan siswa untuk soal nomor 1 sebagian besar pada aturan penjumlahan pada bilangan pecahan. Siswa masih memendang bahwa penjumlahan pecahan sama seperti aturan dalam penjumlahan bilangan bulat. Salah satu contoh kesalahan yang dilakukan oleh siswa dalam menjumlahkan dua pecahan yaitu seperti yang ditunjukkan pada Gambar 1.

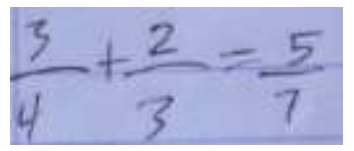

\section{Gambar 1. Kesalahan penjumlahan pecahan siswa}

Jenis kesalahan seperti pada gambar 1 menurut Halimah, dkk (2013) mengungkapkan bahwa pemahaman yang seperti ini kadang masih banyak ditemukan karena siswa masih belum memahami betul konsep penjumlahan pecahan dengan penyebut yang sama dan penjumlahan pecahan dengan penyebut yang tidak sama. Ini disebabkan karena masih lemahnya pengetahuan siswa tentang pecahan, terutama terkait dengan aturan penjumlahan dalam pecahan. Yazid (2003) mengungkapkan bahwa kesulitan paling utama yang dihadapai oleh siswa yaitu ketika menyelesaikan operasi penjumlahan pecahan, karena mereka tidak memahami atau kurangnya pemahaman terhadap proses yang terlibat dengan operasi 
pecahan. Mereka sering melakukan penjumalahan mengikuti aturan pada operasi penjumlahan bilangan bulat tanpa memahami apa yang dimaksud dengan istilah penyebut dan pembilang pada operasi penjumlahan pecahan. Hal senada juga diungkapkan oleh Liu, dkk (2012) mengungkapkan bahwa kesalahan ini juga disebabkan karena kuatnya pembentukan pengetahuan siswa sebelumnya tentang bilangan asli. Kesalahan yang dilakukan pada soal nomor 1 juga berdampak pada hasil kerja siswa dalam menyelesaikan soal nomor 2.

Kesalahan siswa dalam menyelesaikan soal nomor 2, selain karena lemahnya pengetahuan siswa dalam aturan perhitungan penjumlahan pecahan, juga karena ketidakmampuan siswa dalam membalikan pemikiran mereka dalam menggambarkan kondisi awal penjumlahan berdasarkan hasil yang diketahui dari penjumlahan tersebut. Kesalahan ini juga terletak pada ketidakmampuan siswa dalam membangun hubungan yang reversibel. Membangun hubungan yang reversibel dibutuhkan proses dalam aktivitas mental seseorang. Aktivitas mental yang terjadi dalam seseorang dalam membuat suatu keputusan melalui proses hubungan yang reversibel merupakan aktivitas dalam berpikir reversibel. Tindakan dalam berpikir reversibel juga diperlukan dalam menyelesaikan soal nomor 3 .

Semua siswa yang mengikuti tes untuk soal nomor 3 tidak ada yang berhasil. Selain karena ketidakmempuan siswa dalam membagun hubungan yang reversibel dan lemahnya pengetahuan siswa terhadap aturan dalam operasi pecahan, ini juga dikarenakan siswa tidak mampu dalam menggambarkan penjumlahan dua pecahan yang melibatkan tanda negative. Jika untuk soal nomor 2, beberapa siswa dapat menemukan nilai yang hilang berdasarkan hasil penjumlahan dua bilangan pecahan melalui proses hubungan reversibel antara objek-1 dengan objek-2. Objek-1 merupakan dua bilangan pecahan, dalam hal ini yang akan dijumlahkan. Namun dalam soal nomor 2 dan nomor 3 pada penelitian ini yang diketahui adalah hanya satu bilangan pecahan dari objek-1 yaitu $\frac{3}{5}$ untuk soal nomor 2 , dan sementara satu bilangan pecahan yang lain tidak diketahui atau bilangan yang harus ditemukan dalam soal ini. Objek-2 yaitu 1 merupakan hasil perhitungan bilangan dari objek-1. Keberhasilan beberapa siswa dalam menyelesaikan soal nomor 2 disebabkan karena siswa mencari hasil penjumlahan pembilang (bilangan pecahan yang tidak diketahui) dengan pembilang " 3 " dari bilangan pecahan yang telah diketahui pada objek-1, sehingga diperoleh nilai yang sama dengan penyebut pada bilangan pecahan yang telah diketahui pada objek-1 yaitu 5. Langkah ini digunakan siswa, agar dapat menemukan hasil yang sama dengan nilai dari objek-2, yaitu “ $\frac{5}{5}$ ” yang merupakan hasil dari perhitungan objek-1 memiliki nilai yang sama dengan 1 pada objek-2. Artinya objek-1 = objek-2 ekuivalen dengan objek-2 = objek 1 , dan ini menujukan bentuk resiprositas dalam reversibilitas. Sementara untuk soal nomor 3, semua siswa yang mengikuti tes tidak dapat menemukan nilai yang hilang berdasarkan hasil penjumlahan dua bilangan pecahan melalui proses hubungan reversibel antara objek 1 dengan objek 2. Oleh karena itu, kesalahan siswa dalam hal ini terletak pada menggambarkan penjumlahan dua 
bilangan pecahan yang melibatkan bilangan negative dengan mengacu pada hubungan reversibel antara objek-1 dan objek-2.

\section{SIMPULAN DAN SARAN}

Hasil penelitian ini dapat disimpulkan bahwa sebagian besar kesalahan yang dilakukan siswa terletak pada penjumlahan pecahan yang terkait dengan reversibilitas. Lemahnya reversibiltas siswa dalam operasi penjumlahan pecahan salah satunya disebabkan karena siswa hampir tidak pernah diberikan soal penjumlahan pecahan terkait dengan reversibilitas. Selain itu, kesalahan siswa dalam operasi penjumlahan pecahan juga melibatkan beberapa jenis kesalahan, antara lain: Kesalahan yang ditemukan berdasarkan hasil kerja siswa dalam menyelesaikan soal operasi penjumlahan bilangan pecahan dan operasi bilangan pecahan terkait reversibilitas, yaitu antara lain: (1) Siswa masih memendang bahwa penjumlahan pecahan sama seperti aturan dalam penjumlahan bilangan bulat; (2) Lemahnya kemampuan siswa dalam membalikan pemikiran mereka dalam menggambarkan kondisi awal penjumlahan berdasarkan hasil yang diketahui dari penjumlahan tersebut; (3) Lemahnya kemampuan siswa dalam menggambarkan penjumlahan dua pecahan yang melibatkan bilangan negative berdasarkan hasil penjumlahan yang telah diketahui; (4) Lemahnya kemampuan siswa dalam membangun hubungan yang reversibel.

\section{DAFTAR RUJUKAN}

Apriyanto, T. (2012). Analisis Kesalahan Siswa Dalam Menyelesaikan Soal Operasi Hitung Pada Bilangan Pecahan Siswa kelas VII SMP PGRI Banyubiru. Doctoral dissertation, Program Studi Pendidikan Matematika FKIP-UKSW.

Halimah, I. N., \& Poerwanti, J. I. (2013). Penggunaan Media Blok Pecahan Untuk Meningkatkan Kemampuan Penjumlahan Bilangan Pecahan Sederhana. Jurnal Didaktika Dwija Indria, 1(7).

Kang, M. K., \& Lee, B. S. (1999). On Fuzzified Representation of Piagetian Reversible Thinking. Research in Mathematical Education, 3(2), 99-112.

Liu. C., Xin, Z., \& Li, X.,. (2012). The Development of Chinese Students' Understanding of the Concept of Fractions from Fifth to Eighth Grade. Journal of Mathematics Education, 5(1), 45-62.

Maf'ulah. (2016). Profil reversibilitas siswa SD pada operasi hitung bilangan bulat ditinjau dari perbedaan kemampuan matematika dan perbedaan gender. Disertation. Tidak dipublikasikan.

Mullis, I. V. (1997). Mathematics Achievement in the Primary School Years. IEA's Third International Mathematics and Science Study (TIMSS). TIMSS International Study Center, Center for the Study of Testing, Evaluation, and Educational Policy, Campion Hall, School of Education, Boston College, Chestnut Hill, MA 02167. http://wwwcsteep.bc.edu/timss.

Nawawi, H., \& Martini, H. (1992). Instrumen Penelitian Bidang Sosial. Yogyakarta: Gadjah Mada University Press.

Piaget, J. (1971). Genetic Epistemology. Columbia: Columbia University Press.

Ramful, A. (2015). Reversible reasoning and the working backwards problem solving strategy. Australian Mathematics Teacher, The, 71(4), 28. 
Salleh, Z., Saad, N. M., Arshad, M. N., Yunus, H., \& Zakaria, E. (2013). Analisis Jenis Kesilapan Dalam Operasi Penambahan dan Penolakan Pecahan (Error Analysis of Addition and Subtraction of Fractions). Jurnal Pendidikan Matematik, 1(1), 1-10.

Sari, E. A. P., Juniati, D., \& Patahudin, S. M. (2014). Early fractions learning of 3rd grade students in SD Laboratorium Unesa. Journal on Mathematics Education, 3(1), 1728.

Untari, E. (2014). Diagnosis Kesulitan Belajar Pokok Bahasan Pecahan pada Siswa Kelas V Sekolah Dasar. Jurnal Ilmiah STKIP PGRI Ngawi, 13(1), 1-8.

Van, N. T. (1999). Successes and Obstacles in the Development of Grade 6 Learners' Conceptions Of Fractions. Paper presented at the 5th Annual Congress of the Association for Mathematics Education of South Africa (AMESA), Port Elizabeth, 5-9 July 1999.

Widiyanti, P., \& Yani, A. (2015). Analisis Kesulitan Siswa Dalam Menyelesaikan Soal Materi Pecahan Bentuk Aljabar di Kelas VIII SMP. Jurnal Pendidikan dan Pembelajaran, 4(9).

Yazid, Z. (2003). Kesukaran pelajar sekolah rendah dalam memahami konsep pecahan. Prosiding Seminar Penyelidikan MPSMB 2003 (pp. 71-82). 